\title{
Comparison of Serum Hepatitis B Virus DNA and HBsAg Levels Between HBeAg-Negative and HBeAg-Positive Chronic Hepatitis B Patients
}

\author{
Maryam Keshvari $^{1,2,3}$; Seyed Moayed Alavian ${ }^{2,3} ;$ Heidar Sharafi $^{2,3,{ }^{*}}$ \\ ${ }_{1}^{1}$ Blood Transfusion Research Center, High Institute for Research and Education in Transfusion Medicine, Tehran, IR Iran \\ ${ }^{2}$ Middle East Liver Diseases (MELD) Center, Tehran, IR Iran \\ 3 Iran Hepatitis Network, Tehran, IR Iran \\ *Corresponding author: Heidar Sharafi, Middle East Liver Diseases (MELD) Center, Tehran, IR Iran. Tel:+98-2188945186, Fax:+98-2188945188, E-mail: h.sharafi@meldcenter.com
}

Received: June 21, 2014; Revised: August 20, 2014; Accepted: September 6, 2014

Background: Chronic hepatitis B consists of different clinical phases. Laboratory and histological assessments can help differentiate the clinical phases of this disease and thus lead to better management.

Objectives: This study was conducted to determine laboratory and histological characteristics of HBeAg-negative and HBeAg-positive chronic hepatitis B patients.

Patients and Methods: In this study, we evaluated 151 treatment naive chronic hepatitis B patients and grouped them according to their HBeAg status. Serum hepatitis B virus (HBV) DNA and HBsAg levels were measured, and liver function tests, and liver biopsy were performed for the study population.

Results: There was a significant difference in age, and HBV DNA and HBsAg levels between HBeAg-negative and HBeAg-positive groups yet there was no statistically significant difference in sex, liver function tests, grading and staging of liver biopsy between the groups. Hepatitis B virus DNA and HBsAg levels were correlated in both HBeAg-negative and HBeAg-positive chronic hepatitis B patients.

Conclusions: We concluded that chronic hepatitis B patients had different HBV DNA and HBsAg levels according to their HBeAg status.

Keywords:HBeAg; HBsAg; Hepatitis B

\section{Background}

Hepatitis B is a global health problem. According to the World Health Organization report, about 350 million individuals are infected with hepatitis $B$ virus (HBV) and 650,000 patients die due to hepatitis B complications, annually. The spectrum of clinical manifestations of hepatitis $B$ varies between the asymptomatic carrier state and chronic hepatitis, liver cirrhosis, and hepatocellular carcinoma (HCC) (1). Chronic hepatitis B (CHB) consists of two phases: early replicative phase with active liver disease and non- or low-replicative phase with normal liver function (2). During the initial phase of chronic HBV infection, the patients have HBeAg and high levels of HBV DNA in their blood serum (3). The early-replicative phase is predominantly observed in patients who prenatally acquired the infection. The majority of HBeAg-positive patients have high serum HBV DNA and normal alanine transaminase (ALT) levels and show minimal changes on liver biopsy (immune tolerance (IT) phase).

Most of the patients in the IT phase develop CHB with high HBV DNA and ALT levels in their later life (immune clearance (IC) phase) (4). Among patients in the IC phase, the annual rate of HBeAg clearance is about $8 \%$ to $12 \%$. After HBeAg seroconversion, some patients enter the non- or low-replicative phase which is characterized by normal serum ALT concentration, absence of HBeAg and presence of anti-HBeAb, low or undetectable HBV DNA in serum, and minimal or no histological changes on liver biopsy while, some cases continue to have moderate levels of HBV replication and high levels of ALT with moderate to severe changes on liver biopsy in the absence of HBeAg. This presentation can be explained by the presence of HBV variants with mutations in the precore or basal core promoter regions (5). Precore and basal core promoter variants were observed more in HBV genotype $\mathrm{D}$, which was found to be the most prevalent isolated genotype of HBV from patients in Iran $(6,7)$. These cases usually have more progressive forms of liver disease than HBeAg-positive patients (8). Recently, a quantitative HBsAg assay has been introduced for evaluation of treatment response to interferon and assistance in diagnosis of HBV clinical stages.

\section{Objectives}

In this study, we aimed to assess different laboratory and histological characteristics of HBeAg-negative and HBeAg-positive CHB.

\section{Patients and Methods}

The present study included a total of 151 treatment na-

Copyright (C) 2015, Ahvaz Jundishapur University of Medical Sciences. This is an open-access article distributed under the terms of the Creative Commons Attribution-NonCommercial 4.0 International License (http://creativecommons.org/licenses/by-nc/4.0/) which permits copy and redistribute the material just in noncommercial usages, provided the original work is properly cited. 
ive patients with CHB, who were referred to the Tehran Blood Transfusion Hepatitis Clinic (Tehran, Iran) from 2011-2013. Informed consent was obtained from all patients whom participated in this study. This study was approved by the Ethics Committee of the Iranian Blood Transfusion Organization. The study protocol conforms to the ethical guidelines of the 1975 declaration of Helsinki. The criteria for diagnosis of CHB were the presence of HBsAg in the patient's serum for more than six months, HBeAg positivity or serum HBV DNA $>20,000$ $\mathrm{IU} / \mathrm{mL}$, persistent or intermittent elevation in ALT/aspartate transaminase (AST) levels, and/or liver biopsy showing chronic hepatitis with moderate to severe necroinflammation (9).

Individuals with positive serology for human immunodeficiency virus, hepatitis D virus, and hepatitis $C$ virus were excluded from the study. Also, patients with inactive HBV carrier state were excluded. The study population was divided into two study groups of HBeAg-negative and HBeAg-positive CHB. Laboratory assessments including liver function tests, HBV DNA and HBsAg quantification (HBV DNA and HBsAg levels) were assessed for the study population. Upper normal limit of ALT was considered $34 \mathrm{IU} / \mathrm{L}$ for non-overweight wom- en (BMI of less than 25) and $40 \mathrm{IU} / \mathrm{L}$ for non-overweight men (10). Hepatitis B virus DNA level using COBAS TaqMan HBV test (Roche Diagnostics), HBsAg level using HBsAg II quant assay (Roche Diagnostics) and liver biopsy (the results were reported by hepatitis activity index or grading and fibrosis scores or staging according to the scheme introduced by Ishak) were assessed (11). On liver biopsy, liver fibrosis score (stage) $\leq 2$ and liver necroinflammation score (grade) $\leq 4$ were considered as cutoff values to show mild liver damage (12).

The liver histological assessment was not obligatory for stratification of liver disease in patients with high HBV DNA level $(>20,000 \mathrm{IU} / \mathrm{mL})$ and/or ALT of more than two folds of upper normal limit since the diagnosis of CHB was definite in these patients (9). Comparison between categorical variables was performed using Fisher's exact test and comparison between continuous variables was performed using t-test or Mann-Whitney $U$ test. The correlation between HBV DNA and HBsAg levels were analyzed using Spearman's rank correlation test. $P$ values of less than 0.05 were considered to be statistically significant. Statistical analysis was performed using the SPSS software version 20. Also, statistical graphs were generated using GraphPad Prism version 6 .

\begin{tabular}{|c|c|c|c|c|}
\hline & $\begin{array}{l}\text { All Patients } \\
(n=151)\end{array}$ & $\begin{array}{l}\text { HBeAg-Negative } \\
\text { Patients }(n=121)\end{array}$ & $\begin{array}{c}\text { HBeAg-Positive } \\
\text { Patients }(n=30)\end{array}$ & P Value \\
\hline Sex & & & & $0.82^{\mathrm{C}}$ \\
\hline Male & $110(72.8)$ & $89(73.6)$ & $21(70.0)$ & \\
\hline Female & $41(27.2)$ & $32(26.4)$ & $9(30.0)$ & \\
\hline Age, $y$ & $40.9 \pm 14.2$ & $43.5 \pm 13.4$ & $30.5 \pm 13.0$ & $<0.01^{\mathrm{d}}$ \\
\hline Liver fibrosis & & & & $0.29^{C}$ \\
\hline Mild & $77(57.0)$ & $59(54.6)$ & $18(66.7)$ & \\
\hline Moderate to severe & $58(43.0)$ & $49(45.4)$ & $9(33.3)$ & \\
\hline Liver inflammation & & & & $0.35^{\mathrm{C}}$ \\
\hline Mild & $49(38.9)$ & $42(41.2)$ & $7(29.2)$ & \\
\hline Moderate to severe & $77(61.1)$ & $60(58.8)$ & $17(70.8)$ & \\
\hline Serum ALT & & & & $0.25^{\mathrm{C}}$ \\
\hline Normal & $40(26.5)$ & $35(28.9)$ & $5(16.7)$ & \\
\hline Abnormal & $111(73.5)$ & $86(71.1)$ & $25(83.3)$ & \\
\hline Serum ALT, IU/L & $68.3 \pm 49.3$ & $69.0 \pm 53.3$ & $63.4 \pm 27.4$ & $0.42^{\mathrm{d}}$ \\
\hline Serum AST, IU/L & $45.8 \pm 26.4$ & $46.7 \pm 28.1$ & $41.5 \pm 17.6$ & $0.33^{\mathrm{d}}$ \\
\hline Serum direct bilirubin, mg/dL & $0.4 \pm 0.3$ & $0.4 \pm 0.3$ & $0.3 \pm 0.2$ & $0.08^{\mathrm{d}}$ \\
\hline Serum total bilirubin, mg/dL & $1.2 \pm 0.8$ & $1.2 \pm 0.8$ & $0.9 \pm 0.4$ & $0.07^{\mathrm{d}}$ \\
\hline HBV DNA level, Log IU/mL, Median(IQR) & $5.5(7.2)$ & $5.1(6.0)$ & $9.0(9.1)$ & $<0.01^{\mathrm{e}}$ \\
\hline HBsAg level, Log IU/mL, Median (IQR) & $3.8(4.7)$ & $3.6(4.0)$ & $4.6(5.0)$ & $<0.01^{\mathrm{e}}$ \\
\hline
\end{tabular}


Figure 1. Correlation Between Hepatitis B Virus DNA and HBsAg Levels in Chronic Hepatitis B Patients

a

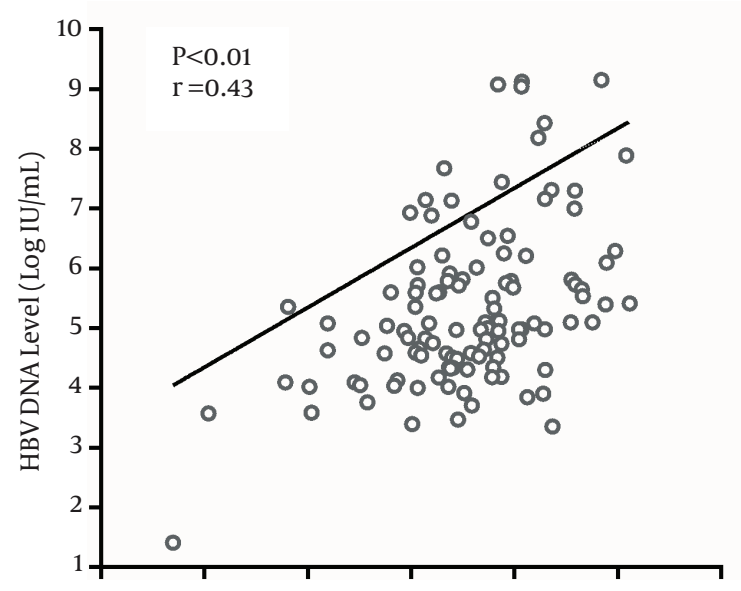

b

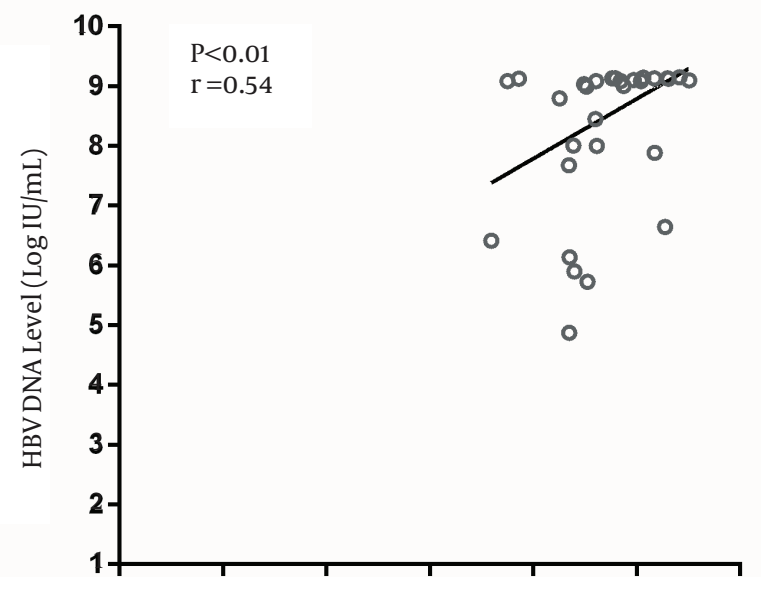

a, HBeAg-negative CHB ( $\mathrm{n}=121)$; b, HBeAg-positive $\mathrm{CHB}(\mathrm{n}=30)$.

\section{Results}

In this study, among the 151 treatment naive $\mathrm{CHB}$ patients, 121 (80.1\%) were HBeAg-negative and 30 (19.9\%) were HBeAg-positive. Among HBeAg-positive patients, five cases were in the IT phase and 25 were in the IC phase. HBeAg-negative patients were generally older than HBeAg-positive cases $(\mathrm{P}<0.01)$. There was no statistically significant difference in sex, liver inflammation and fibrosis, serum AST, ALT and bilirubin between the two study groups ( $\mathrm{P}>0.05)$ (Table 1$)$. The proportion of patients with moderate to severe fibrosis on liver biopsy was higher in HBeAg-negative cases than HBeAg-positive patients yet this difference was not statistically significant $(\mathrm{P}=0.29)$ (Table 1$)$. Hepatitis B virus DNA and HBsAg levels were significantly higher in $\mathrm{HBeAg}$-positive $\mathrm{CHB}$ cases than in HBeAg-negative CHB patients $(\mathrm{P}<0.01)$ (Table 1). Ninety percent of HBeAg-positive patients had HBV DNA and HBsAg levels higher than $6 \log 10 \mathrm{IU} / \mathrm{mL}$ and 4 $\log 10 \mathrm{IU} / \mathrm{mL}$, respectively whereas, around $25 \%$ of $\mathrm{HBeAg}$ negative cases had HBV DNA and HBsAg levels above 6 $\log 10 \mathrm{IU} / \mathrm{mL}$ and $4 \log 10 \mathrm{IU} / \mathrm{mL}$, respectively $(\mathrm{P}<0.01)$. Hepatitis B virus DNA and HBsAg levels correlated in both HBeAg-negative $(\mathrm{r}=0.43, \mathrm{P}<0.01)$ (Figure $1 \mathrm{a})$ and HBeAgpositive patients $(\mathrm{r}=0.54, \mathrm{P}<0.01$ ) (Figure $1 \mathrm{~b}$ ).

\section{Discussion}

Different studies have reported that HBeAg-positive CHB patients had higher HBV viral load than HBeAg-negative $\mathrm{CHB}$ cases $(13,14)$. In the present study, HBV DNA and HBsAg levels were significantly higher in HBeAg-positive than in HBeAg-negative CHB cases. In the study by Chu et al. (15), among CHB patients, HBV DNA level of more than $20,000 \mathrm{IU} / \mathrm{mL}$ was detected in $96 \%$ of HBeAg-positive cas- es. In our study, a significant proportion of HBeAg-positive patients had HBV DNA levels of more than $6 \log 10 \mathrm{IU} /$ $\mathrm{mL}$ while a small proportion of HBeAg-negative patients had HBV DNA levels of more than this cutoff value. Other studies demonstrated that HBsAg levels were higher in IT-patients and IC-patients compared to patients in lowreplicative and HBeAg-negative $\mathrm{CHB}$ phases $(16,17)$.

In the present study, we did not find any significant difference in ALT, AST and bilirubin levels between the two studied groups. A previous study reported higher levels of ALT, AST and bilirubin in HBeAg-negative CHB patients compared to HBeAg-positive CHB individuals (18) whereas, a Chinese study showed higher levels of ALT in HBeAg-positive CHB than in HBeAg-negative CHB individuals (19). Although we found no significant difference in inflammation and fibrosis on liver biopsy according to the patients' HBeAg status, HBeAg-positive patients had lower fibrosis score than HBeAg-negative patients. A study from China found that hepatic necroinflammation grading and fibrosis staging in the HBeAg-negative group were more advanced than in the HBeAg-positive group (19). In another study, the HBeAg status had no association with the grade of liver inflammation and the stage of liver fibrosis in CHB patients (20).

It seems that there is a correlation between serum HBsAg and HBV DNA levels although the results regarding this issue are conflicting. We found a positive correlation between HBV DNA and HBsAg levels in both studied groups. The studies by Chan et al. (21) and Ramachandran et al. (22) showed that there was a stronger correlation between HBV DNA and HBsAg levels in HBeAg-positive $\mathrm{CHB}$ patients than in the HBeAg-negative $\mathrm{CHB}$ patients. In another study, there was a correlation between serum 
HBV DNA and HBsAg levels only during the IC phase (23). According to a study from Iran, there was no correlation between HBV DNA and HBsAg levels in CHB patients (24). On the other hand, in a European study, there was a correlation between HBsAg and HBV DNA levels in patients infected with HBV genotype D but no such correlation in patients infected with HBV genotype A (16). The main limitation of our study was the small number of HBeAgpositive patients, especially patients in the IT phase. The reason for this limitation was the low percentage of HBeAg positivity among Iranian HBV-infected patients. We propose a study with a larger sample size of HBeAgpositive cases who are in the IT and IC phases.

In conclusion, the present study demonstrated that HBeAg-negative and HBeAg-positive CHB patients are distinct considering HBV DNA and HBsAg levels.

\section{Acknowledgements}

We gratefully acknowledge the help of the Hepatitis Clinic of Tehran Blood Transfusion Center and Middle East Liver Diseases (MELD) Center staff.

\section{Authors' Contributions}

Maryam Keshvari, Seyed Moayed Alavian designed the study, Heidar Sharafi analyzed the data, and Maryam Keshvari, Seyed Moayed Alavian and Heidar Sharafi wrote the manuscript.

\section{References}

1. Sugauchi F, Chutaputti A, Orito E, Kato H, Suzuki S, Ueda R, et al. Hepatitis B virus genotypes and clinical manifestation among hepatitis B carriers in Thailand. J Gastroenterol Hepatol. 2002;17(6):671-6.

2. Hoofnagle JH, Dusheiko GM, Seeff LB, Jones EA, Waggoner JG, Bales ZB. Seroconversion from hepatitis B e antigen to antibody in chronic type B hepatitis. Ann Intern Med.1981;94(6):744-8.

3. Krajden M, McNabb G, Petric M. The laboratory diagnosis of hepatitis B virus. Can J Infect Dis Med Microbiol. 2005;16(2):65-72.

4. Lok AS, McMahon BJ. Chronic hepatitis B. Hepatology. 2007;45(2):507-39.

5. McMahon BJ. Epidemiology and natural history of hepatitis B. Semin Liver Dis. 2005;25 Suppl 1:3-8.

6. Garmiri P, Rezvan H, Abolghasemi H, Allain JP. Full genome characterization of hepatitis B virus strains from blood donors in Iran. J Med Virol. 2011;83(6):948-52.

7. Haghshenas MR, Arabi M, Mousavi T. Hepatitis B genotypes in iran. Mater Sociomed. 2014;26(2):129-33.

8. Yuan HJ, Yuen MF, Ka-Ho Wong D, Sum SM, Sablon E, Ng IO, et al. Impact of precore and core promoter mutations on hepatic histology in patients with chronic hepatitis B. Aliment Pharmacol Ther. 2005;22(4):301-7.

9. Lok AS, McMahon BJ. Chronic hepatitis B: update 2009. Hepatology. 2009;50(3):661-2.

10. Mohamadnejad M, Pourshams A, Malekzadeh R, Mohamadkhani A, Rajabiani A, Asgari AA, et al. Healthy ranges of serum alanine aminotransferase levels in Iranian blood donors. World J Gastroenterol. 2003;9(10):2322-4.

11. Goodman ZD. Grading and staging systems for inflammation and fibrosis in chronic liver diseases. J Hepatol. 2007;47(4):598-607.

12. Fateen AA, Shahin RY, Farres MN, Eldeeb MA, Amer HA. Assessment of hepatic fibrosis and necroinflammation among inactive HBsAg carriers in Egypt. Ann Hepatol. 2012;11(4):464-70.

13. Lok AS, Lai CL. A longitudinal follow-up of asymptomatic hepatitis B surface antigen-positive Chinese children. Hepatology. 1988;8(5):1130-3.

14. Su TH, Hsu CS, Chen CL, Liu CH, Huang YW, Tseng TC, et al. Serum hepatitis B surface antigen concentration correlates with HBV DNA level in patients with chronic hepatitis B. Antivir Ther. 2010;15(8):1133-9.

15. Chu CJ, Hussain M, Lok AS. Quantitative serum HBV DNA levels during different stages of chronic hepatitis B infection. Hepatology. 2002;36(6):1408-15.

16. Jaroszewicz J, Calle Serrano B, Wursthorn K, Deterding K, Schlue J, Raupach R, et al. Hepatitis B surface antigen (HBsAg) levels in the natural history of hepatitis B virus (HBV)-infection: a European perspective. J Hepatol. 2010;52(4):514-22.

17. Zeng LY, Lian JS, Chen JY, Jia HY, Zhang YM, Xiang DR, et al. Hepatitis B surface antigen levels during natural history of chronic hepatitis B: a Chinese perspective study. World J Gastroenterol. 2014;20(27):9178-84.

18. Bahramali G, Sadeghizadeh M, Amini-Bavil-Olyaee S, Alavian SM Behzad-Behbahani A, Adeli A, et al. Clinical, virologic and phylogenetic features of hepatitis B infection in Iranian patients. World J Gastroenterol. 2008;14(35):5448-53.

19. Yang CG, Yu YC, Chen JJ, Sun J, Guo YB, Luo KX, et al. [A comparison of clinical and virological characteristics of 1686 cases of HBeAgnegative and HBeAg-positive chronic hepatitis B]. Zhonghua Nei Ke Za Zhi. 2005;44(9):648-51.

20. Liu SQ, Zhu XJ, Sun XH, Li M, Gao YQ. [Characteristic of liver pathology in HBeAg-positive and HBeAg-negative chronic hepatitis $\mathrm{B}$ patients with mildly elevated ALT]. Zhonghua Gan Zang Bing Za Zhi. 2012;20(5):348-52.

21. Chan HL, Wong VW, Wong GL, Tse CH, Chan HY, Sung JJ. A longitudinal study on the natural history of serum hepatitis $\mathrm{B}$ surface antigen changes in chronic hepatitis B. Hepatology. 2010;52(4):1232-41.

22. Ramachandran J, Ismail AM, Chawla G, Fletcher GJ, Goel A, Eapen CE, et al. Serum HBsAg quantification in treatment-naive Indian patients with chronic hepatitis B. Indian J Gastroenterol. 2014;33(2):131-5.

23. Nguyen T, Thompson AJ, Bowden S, Croagh C, Bell S, Desmond PV, et al. Hepatitis B surface antigen levels during the natural history of chronic hepatitis B: a perspective on Asia. J Hepatol. 2010;52(4):508-13.

24. Ganji A, Esmaeilzadeh A, Ghafarzadegan K, Helalat H, Rafatpanah $\mathrm{H}$, Mokhtarifar A. Correlation between HBsAg quantitative assay results and HBV DNA levels in chronic HBV. Hepat Mon. 2011;11(5):342-5. 